\title{
DESIGN AND DEVELOPMENT OF SCR SYSTEM FOR NOX REDUCTION BY USING VARIOUS CATALYSTS
}

\author{
Mr. Raju B Tirpude \\ Lecturer \\ Automobile Engineering \\ Department \\ Government \\ Polytechnic, Nagpur
}

\author{
Dr. S.W. Rajurkar \\ Dept. of Mech. Engg. \\ Government \\ Engineering, College, \\ Chandrapur
}

\author{
Dr. G.K.Awari \\ Head of Automobile \\ Engineering \\ Department \\ Government \\ Polytechnic, Nagpur
}

\author{
Mr. Ashish M. \\ Wankhede \\ Lecturer \\ Automobile Engineering \\ Department \\ Government \\ Polytechnic, Nagpur
}

\begin{abstract}
Diesel engines are generally used in many areas like automobile industry, locomotive industry, power generation etc. due to its high break power output and thermal efficiency. An oxide of nitrogen (NOx) is one of the most hazardous pollutants which come out from diesel IC engine through tail pipe. Emission of nitrogen oxide (NOx) contribute significantly to our environment, which is a savior environmental problem of NOx which reacts with in the air to form nitric acid $\left(\mathrm{HNO}_{3}\right)$, contributing to soil eruption and water acidification in sensitive and metropolitan areas. Various present technologies available for NOx reduction either increases other polluting gas emission on increase fuel consumption in an IC engine. Selective catalyst reduction systems (SCR) are the most effective and commonly used post combustion NOx reduction processes available in automobile and power generation sector. SCR utilizes a chemical reaction where vaporized ammonia $\left(\mathrm{NH}_{3}\right)$ is collected from the mixture of Urea and distilled water. Various catalysts are injected into the exhaust gases. The prime objective is to convert nitrogen oxide (NOx) to nitrogen $\left(\mathrm{N}_{2}\right)$ and water $\left(\mathrm{H}_{2} \mathrm{O}\right)$. The existing SCR system is a modified by adding some of the component and use various catalysts injected in tail pipe through feed pump. It has been observed that the NOx is reduced due to new SCR system. This process is called as deNOxtation process. In this SCR system denotation level has been reduced, and also contribute to reducing NOx by 65 to $70 \%$.
\end{abstract}

Keywords - Exhaust gas emission, Diesel emission control system; advance $\mathrm{SCR}$, Urea, Catalyst, Ammonia $\left(\mathrm{NH}_{3}\right)$

\section{INTRODUCTION}

As per Honorable Supreme Court decision the emission norms in India will be changed with effect from the year of 2020 as given below.

\begin{tabular}{|c|c|c|c|c|c|}
\hline stage & date & CO & HC & HC+NOx & PM \\
\hline & \multicolumn{5}{|c|}{ Gram/km } \\
\hline \multicolumn{7}{|c|}{ Compression ignition (diesel engine) } \\
\hline BS IV & 2010 & 0.5 & - & 0.3 & 0.025 \\
\hline BS VI & 2020 & 0.5 & - & 0.17 & 0.0045 \\
\hline Euro 6 & 2014 & 0.5 & - & 0.17 & 0.005 \\
\hline \multicolumn{7}{|c|}{ Spark ignition (petrol engine) } \\
\hline Bs IV & 2010 & 1 & 0.1 & 0.08 & - \\
\hline Bs VI & 2020 & 1 & 0.1 & 0.06 & 0.0045 \\
\hline Euro 6 & 2014 & 1 & 0.1 & 0.06 & 0.005 \\
\hline
\end{tabular}

A EURO-VI norm has the stringent limits of emission standards legislation, Selective Catalytic Reduction (SCR) technology has been used in automobile sector. The maximum NOx conversion efficiency of SCR depends upon temperature and mass flow rate $\left(\mathrm{m}_{\mathrm{f}}\right)$ of an exhaust gas emission. Nowadays the necessity for the SCR technology is continuously increasing due to the fact that the emission legislation has been expanded into the non-road market. To convert nitrogen oxides (NOx) the nitrogen $\left(\mathrm{N}_{2}\right)$ and water $\left(\mathrm{H}_{2} \mathrm{O}\right)$ separation is the main objective of this distinct SCR technology system which is more efficient than existing SCR systems. The key is to reform the chemical reaction that is called as deNOxtation process.

Ammonia $\left(\mathrm{NH}_{3}\right)$ or urea $\left(\mathrm{NH}_{2}-\mathrm{CO}-\mathrm{NH}_{2}\right)$ is used as reducing agent in SCR system. When urea and distilled water combined as a mixture, then formation of ammonia $\left(\mathrm{NH}_{3}\right)$ which is injected in tail pipe through feed pump. Automobile manufactures focused their attention towards the further improvement of the technique to make it suitable for 


\section{International Journal of Engineering Applied Sciences and Technology, 2019 \\ Vol. 4, Issue 6, ISSN No. 2455-2143, Pages 337-343 \\ Published Online October 2019 in IJEAST (http://www.ijeast.com)}

automobiles having diesel engines. Reduction of catalytic converter volume at low temperatures and the suitable dosing strategy for $\mathrm{NH}_{3}$ at frequently on diesel engines with the help of digital exhaust gas analyzer involved with modified SCR systems. Additionally, the risk associated concerning storing and handling of gaseous $\mathrm{NH}_{3}$ is significant. It is not commonly used as a reducing agent directly because; ammonia is very toxic in nature. For reasons of toxic nature of $\mathrm{NH}_{3}$ and handling and storing problems, urea is the preferred substitute for NH3 as a reducing agent in automotive applications. ${ }^{[1]}$

The major pollutant emissions of the diesel engines are NOx, particulate matters, and smoke and soot particles. Although all other emissions, NOx is one of the most important emission from diesel engine. It plays an important role in the atmospheric ozone depletion and global warming. It is also most precursors to the photochemical smog. Component of smog irritate eyes and throat, stir up asthmatic attacks, decrease visibility and damages plants life as well as human life and materials as well. By dissolving with water vapors NOx from acid rain which has direct and indirect affects environmental aspects. ${ }^{[9]}$

This distinct SCR technology permits the NOx reduction reaction to take place in an oxidizing atmosphere. It is called selective because the catalytic reduction of NOx with ammonia(NH), urea, monomethylamine, di-methylamine, try methylamine, cyanuric acid, carbonates, ammonium carbonate, ammonium bicarbonate, etc.. SCR is a process for reducing the concentration of $\mathrm{NO}_{\mathrm{x}}$ from the combustion exhaust, which involves the injection of aqueous solution of urea in the tail pipe of a four stroke. ${ }^{[9]}$

Urea has been selected for reluctant in most of the applications, stored on board in an aqueous solution. To overcome the difficulties associated with pure ammonia, urea is selected. Urea can be hydrolyzed and decomposed to generate ammonia $\left(\mathrm{NH}_{3}\right)$. An injected aqueous solution of urea solution is decomposed into ammonia and water vapour, and then decomposed ammonia reacts with oxides of nitrogen and reduced into eco-friendly nitrogen $\left(\mathrm{N}_{2}\right)$ and water vapor.

Following chemical reactions are prominent in new design of SCR system.

$$
\begin{aligned}
& \left.\left(\mathrm{NH}_{2}\right) .2 \mathrm{CO}+7 \mathrm{H}_{2} \mathrm{O} \rightarrow\left[\left(\mathrm{NH}_{2}\right) 2 \mathrm{CO} .7 \mathrm{H}_{2} \mathrm{O}\right] \ldots \ldots \ldots \ldots . . . .1\right] \\
& \left.\left(\mathrm{NH}_{2}\right) 2 \mathrm{CO} .7 \mathrm{H}_{2} \mathrm{O}\right] \rightarrow \mathrm{HNCO}+\mathrm{NH}_{3}+7 \mathrm{H}_{2} \mathrm{O} \ldots \ldots \ldots . \text { [2] } \\
& 4 \mathrm{NH}_{3}+4 \mathrm{NO}+\mathrm{O}_{2} \rightarrow 4 \mathrm{~N}_{2}+6 \mathrm{H}_{2} \mathrm{O} \ldots \ldots \ldots \ldots \ldots \text {. [3] } \\
& 4 \mathrm{NH}_{3}+3 \mathrm{O}_{2} \rightarrow 2 \mathrm{~N}_{2}+6 \mathrm{H}_{2} \mathrm{O} \text {. }
\end{aligned}
$$

The concept of using urea in modified SCR systems for the reduction of $\mathrm{NO}$ emissions in diesel engines. Since then, many applications have been developed, some of which have reached commercially. But, it is still a challenge for researchers.

\section{LITERATURE SURVEY}

Urea -SCR, the selective catalytic reduction using urea as reducing agent has been investigated for about 10 years in detail and today is a well-established technique for DeNOx of stationary diesel engines. The paper discusses the fundamental problems and challenges if urea-SCR is extended to mobile applications. ${ }^{[1]}$

Choice of catalyst types to reduce the NOx emissions down to Euro V level. A novel urea injection system is also presented, which is based on a mass produced dosing pump that is combined with an electronic control unit. The results indicated that it is possible to have a $\mathrm{NO}_{x}$ conversion above $80 \%$ with ammonia slip below 10ppm using 30 liters of urea on 130 cpsi catalysts for a 12 cylinder diesel engine. ${ }^{[2]}$

Selective Catalytic Reduction technology is being applied for controlling emissions on oxides of nitrogen from coal-fired boilers. The vanadium and titanium oxides, used commonly in the vandia-titania SCR catalyst for NOx reduction. ${ }^{[3]}$

Injection of aqueous solutions of urea in the exhaust for the reduction of NOx in a single cylinder light duty DI diesel engine. Several kinds of concentration of urea solution varying from 10 to $40 \%$ by weight with different flow rates of urea solution varying from $250 \mathrm{ml} / \mathrm{hr}$ to $750 \mathrm{ml} / \mathrm{hr}$ were tested by fitting vanadium as catalyst which improved the chemical reactions even at a lower temperature of $190^{\circ} \mathrm{C}$. Results showed that a maximum of $27.46 \%$ of $\mathrm{NO}_{\mathrm{X}}$ reduction was achieved with an optimised flow rate of $0.75 \mathrm{lit} / \mathrm{hr}$ with $10 \%$ urea concentration. ${ }^{[4]}$

The performance, combustion and emission characteristics on CI engine fuelled with cotton seed oil blends of $25 \%, 50 \% 75 \%$ and $100 \%$ in volume. Due to increase of oxides of nitrogen compared to neat diesel, the Selective catalytic Reduction system was implemented in exhaust pipe. The results indicated that the amount of oxides of nitrogen was decreased rapidly on injection of $30 \%$ concentration of urea solution. ${ }^{[5]}$

The injection of aqueous solutions of urea in the tail pipe of a diesel engine. Four observations were made for the exhaust emission $\mathrm{NO}$ analysis of concentration of urea solution 0 to $30 \%$ by weight with different flow rates of urea solution as reluctant by fitting marine ferromanganese nodule as SCR catalyst. It was observed that $64 \%$ of NOx reduction was achieved. ${ }^{[6]}$

The use to fully understand the impacts of biodiesel on the diesel engine combustion process and pollutant formation. This paper is more concerned with an experimental investigation to study the diesel engine emission characteristics using Mahua biodiesel with the help of a Three Way Catalytic converter with Diesel Exhaust Fluid (DEF) by running the engine. Almost 90\% NOx emissions got reduced and the emission values recorded were much less when 


\section{International Journal of Engineering Applied Sciences and Technology, 2019 \\ Vol. 4, Issue 6, ISSN No. 2455-2143, Pages 337-343 \\ Published Online October 2019 in IJEAST (http://www.ijeast.com)}

compared to Bharat stage- IV Norms for selected engine at all operated loads with retrofit arranged. ${ }^{[7]}$

Pongamia pinata methyl ester (PPME) chosen as an alternative fuel for diesel engines. Injection of aqueous solutions of urea in the tail pipe of a diesel engine fuelled with Pongamia pinata methyl ester (PPME) for the reduction of oxides of nitrogen (NO).Four observations were made for various concentration of urea solution $0 \%, 10 \%, 20 \%$, and $30 \%$ by weight with different flow rates of urea solution as reductant by fitting Marine Ferromanganese nodule as SCR catalyst which improves the chemical reactions. 64\% NOx reduction achieved with the urea flow rate $0.60 \mathrm{lit} / \mathrm{hr}, 30 \%$ concentration of urea solution and marine ferromanganese nodule as SCR. ${ }^{[8]}$

Selective Catalytic Reduction (SCR) technique of reduction of NOx is most suitable for automobile diesel engines to meet the upcoming stringent emission norms. Direct measurement of ammonia storage may increase opportunities for significant improvement. Although the technology is more efficient, there are several drawbacks like ammonia slip, deposit formation, etc. that are associated with it. It requires up gradation of technology. In order to avoid these problems mixers are most commonly used in SCR systems. ${ }^{[9]}$

The characteristics of the element technology of the SCR system had been ascertained, SCR catalyst is added that combined the entire element in single converter. This effort successfully identified specification that enhances NOx conversion performance while finding a balance with soot combustion performance \& pressure loss characteristics. ${ }^{[10]}$

Performance is validated by measuring gas composition as well as NOx conversion across a downstream SCR substrate unit. The use of gaseous $\mathrm{NH}_{3}$ also allow for greater NOx conversion efficiency without deposit formation. ${ }^{[1]}$

While comparing the optimal SCR performance with one and two injectors for two different application with split SCR catalyst, the global optimal dosing control were found in using dynamic programming and the resulting $\mathrm{NOx} \& \mathrm{NH}_{3}$ emissions from those control were compared to quantify possible benefits from the added degree of freedom provided by the second injector. ${ }^{[12]}$

Relevant to model based control design for a Urea based Selective Catalytic Reduction (SCR) process relevant to automotive applications. A three state, control oriented, lumped parameter model of the system is used to investigate essential controllability and observability properties of the Urea-SCR plant. Results from the controllability and observability analysis of both nonlinear and linearized models are shown to have realistic implications. Observer design for predicting gas phase ammonia slip is outlined and results presented. An altered definition of the catalyst efficiency is used in control design. ${ }^{[13]}$

$\mathrm{T}$ he urea decomposition process in diesel exhaust gas was elucidated. Several kinds of urea decomposition catalysts were investigated and the material which showed the best performance in NH3 (ammonia) formation was used to improve the low temperature performance of $\mathrm{Cu}$-zeolite catalysts. ${ }^{[14]}$

The method of reducing the amount of NH3 slip was investigated. It is well known that the amount of ammonia slip after the Urea-SCR system must be under $10 \mathrm{ppm}$ and therefore materials with lower NH3 slip are preferred. The smaller the amount of NH3 slip, the larger the amount of urea that can be injected into the system and this leads to higher NOx conversion. ${ }^{[15]}$

Net soot burn was observed for the 2010 CSF system when operating with standard EGR at the specific conditions chosen for these series of testing. The high passive filter regeneration activity of the SCR-DPF system with the engine operating at high engine-out NOx may result in less frequent active regeneration events and, hence, reduce the fuel penalty associated with active regeneration. The results of this work demonstrated that using SCR-DPF systems not only could meet current NOx reduction regulations but also improve fuel economy for heavy duty diesel vehicles by allowing them to operate at higher engine out NOx conditions. ${ }^{[16]}$

It is demonstrated that such approach is capable of providing enough ammonia not only for small diesel engines, but also for those within typical light and medium duty applications. A pick-up truck demonstration illustrates the initial feasibility of such a system to generate and dose ammonia throughout transient duty cycles; however, much effort is necessary to develop the system for serial production, further proving the many other suggested benefits. Interestingly, the demonstrated results did not require engine modifications, suggesting an option as a Bolton solution for NOx abatement retrofits, necessitating less packaging than an equivalent liquid urea SCR system. ${ }^{[17]}$

Selective Catalytic Reduction (SCR) catalysts have been demonstrated as an effective solution for controlling NOx emissions from diesel engines. There is a drive to reduce the overall packaging volume of the after treatment system for these applications. In addition, more active SCR catalysts will be needed as the applications become more challenging: e.g. lower temperatures and higher engine out NOx, for fuel consumption improvements. One approach to meet the challenges of reduced volume and/or higher NOx reduction is to increase the active site density of the SCR catalyst by coating higher amount of SCR catalyst on high porosity substrates (HPS). This approach could enable the reduction of the overall packaging volume while maintaining similar NOx conversion as compared to $2010 / 2013$ systems, or improve the NOx reduction performance for equivalent volume and $\mathrm{NH} 3$ slip. In this work, systems consisting of SCR coated on high porosity substrates were evaluated in comparison to standard substrate based SCR systems used in typical 2010 applications. ${ }^{[18]}$

Many of the researchers have attempted to preside the solution to NOx emission from the CI engine, but no 


\section{International Journal of Engineering Applied Sciences and Technology, 2019 \\ Vol. 4, Issue 6, ISSN No. 2455-2143, Pages 337-343 \\ Published Online October 2019 in IJEAST (http://www.ijeast.com)}

researcher has provided the efficient design of SCR system using urea solution. An attempt has been made in this research work to design completely new SCR system to reduce the level of NOx emission from the engine.

Following table refers to the pollution board of India for BSIV norms.

\begin{tabular}{|c|c|c|c|c|c|}
\hline Standard & Test Cycles & CO & HC & NOx & PM \\
\cline { 3 - 6 } & & \multicolumn{4}{|c|}{$\mathrm{g} / \mathrm{kWh}$} \\
\hline \multirow{5}{*}{ BS IV } & $\begin{array}{c}\text { European } \\
\text { Steady-state } \\
\text { Cycle (ESC) }\end{array}$ & 1.5 & 0.46 & 3.50 & 0.02 \\
& $\begin{array}{c}\text { European } \\
\text { Transient } \\
\end{array}$ & 4.0 & 0.55 & 3.50 & 0.03 \\
& Cycle (ETC) & & & & \\
\hline
\end{tabular}

Table No. 2: emission norms

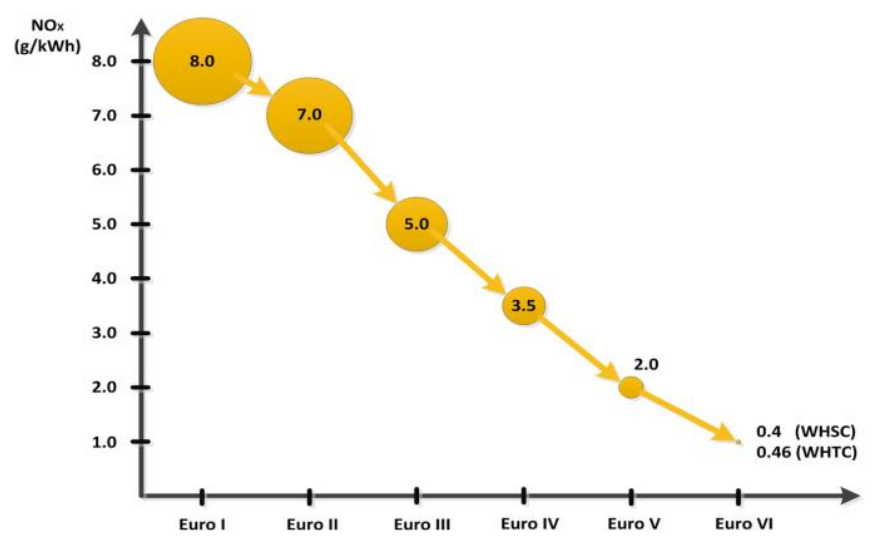

Figure No -1: NOx emission standard according to EURO Standards ${ }^{[10]}$

\section{EXPERIMENTAL SETUP}

New SCR system consists of 2 catalytic converter instead of single catalytic converter. Two catalytic converter arranged in a series connection in order to reduce the NOx emission as shown in experimental block diagram. Pulse width module electronics circuit is used to control the injection timing. In this circuit, in-built RC timer circuit is used.

Injector (solenoid type valve) is used to create high pressure in pump and to inject the aqueous ammonia in tail pipe. Injection system is fixed between the two catalytic converter for injection purpose. High pressure feed pump is attached with high pressure pipe to supply urea solution through injection system and all the setup connected to the DC battery. Experimental setup is shown in figure no 2.

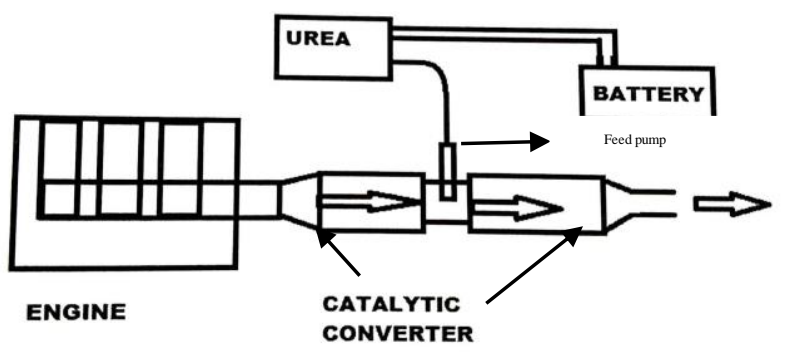

Figure 2: block diagram of New SCR System

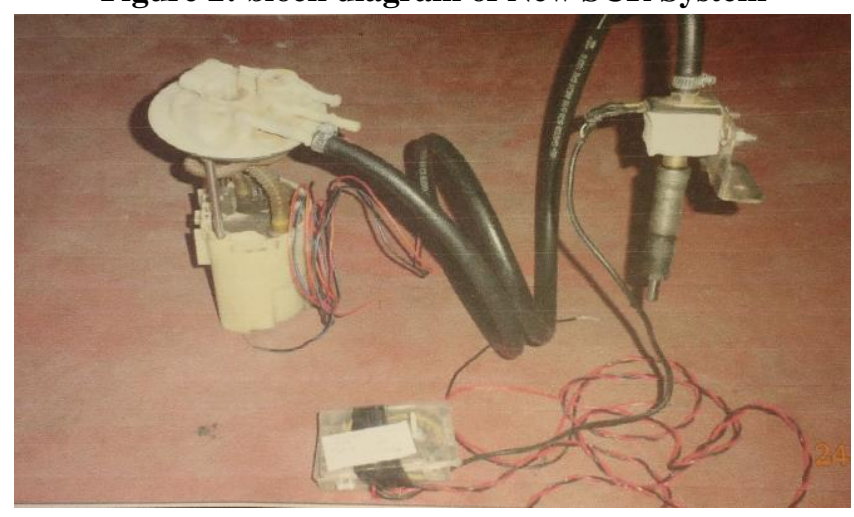

Figure 3: DeNOxtation injection system

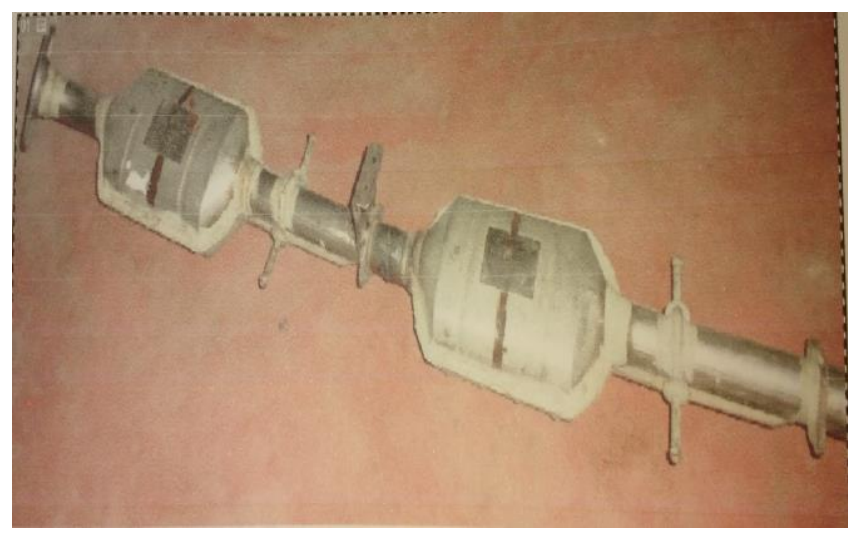

Figure 4:Catalytic converter connected in series for New SCR 
International Journal of Engineering Applied Sciences and Technology, 2019

Vol. 4, Issue 6, ISSN No. 2455-2143, Pages 337-343

Published Online October 2019 in IJEAST (http://www.ijeast.com)

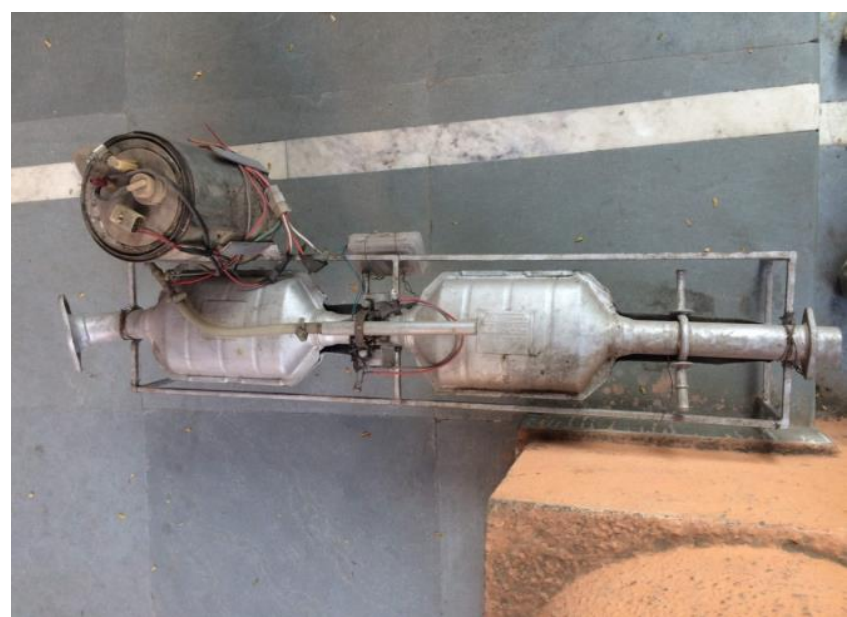

Figure 5: Modified SCR System

\section{METHODOLOGY \& EXPERIMENTATION}

Before starting the engine, urea solution is to be prepared for different concentration varying with 20grams, 30grams and 40 grams by weight along with 1litre of distilled water. Also we make sure that all the connection of control circuit board should be properly enact. The modified SCR should be soot free \& properly functioning. Before starting the operation of the setup is replaced by the new SCR with modified SCR system in diesel vehicle.

Following readings are recorded with the help of flue gas analyzer

1. 20gm of urea/ lit of distilled water NOx $=1.20$ PPM (Part per million)

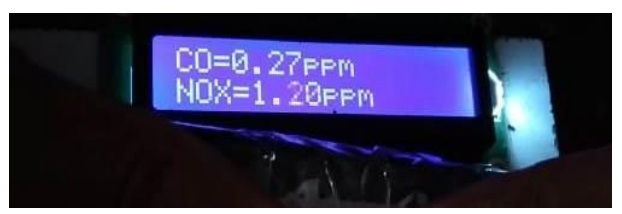

2. $30 \mathrm{gm}$ of urea/ lit of distilled water NOx $=0.90$ PPM (Part per million)

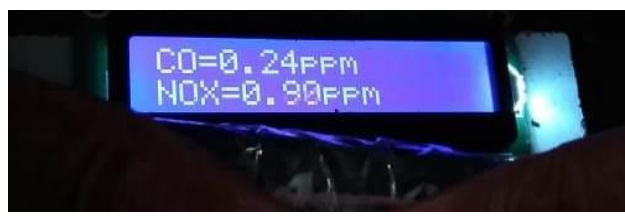

3. 40gm of urea/ lit of distilled water NOx $=$ 0.65 PPM (Part per million)

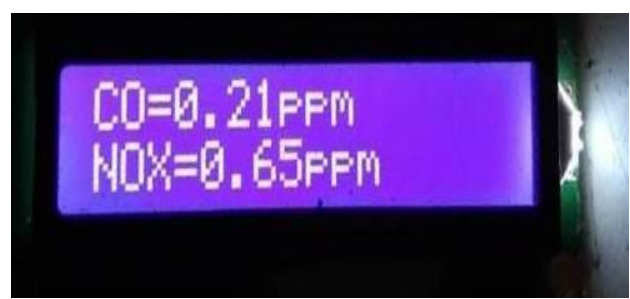

The properly calibrated instruments are used for the measurement of the exhaust gas emission. the calibration is done with the help of standard procedure.

Following exhaust gas analyser is used for the research work.

\begin{tabular}{|c|c|c|}
\hline Conc. of urea solution & NOx & CO \\
\hline $10 \mathrm{~g} /$ lit of distilled water & $1.36 \mathrm{ppm}$ & $0.76 \mathrm{ppm}$ \\
\hline $20 \mathrm{~g} /$ lit of distilled water & $1.20 \mathrm{ppm}$ & $0.27 \mathrm{ppm}$ \\
\hline $30 \mathrm{~g} /$ lit of distilled water & $0.90 \mathrm{ppm}$ & $0.24 \mathrm{ppm}$ \\
\hline $40 \mathrm{~g} /$ lit of distilled water & $0.65 \mathrm{ppm}$ & $0.21 \mathrm{ppm}$ \\
\hline $50 \mathrm{~g} /$ lit of distilled water & $0.46 \mathrm{ppm}$ & $0.19 \mathrm{ppm}$ \\
\hline
\end{tabular}

Table No 4: emmission norms

The experimentation was conducted on no load condition on the following $\mathrm{CI}$ engine.

\section{Engine Specification (CI)}

\begin{tabular}{|l|l|}
\hline Test bed & $\begin{array}{l}\text { 330kw,AVL transient } \\
\text { dynamometer }\end{array}$ \\
\hline Engine specification & $\begin{array}{l}6 \text { cylinder ,inline common } \\
\text { rail }\end{array}$ \\
\hline Bore & $103 \mathrm{~mm}$ \\
\hline Stroke & $114 \mathrm{~mm}$ \\
\hline Gas analyzer & $\begin{array}{l}\text { NOx,Co,HC,raw gas } \\
\text { analyzer }\end{array}$ \\
\hline $\mathrm{NH}_{3}$ measurement & AVL -FTIR \\
\hline $\begin{array}{l}\text { In cylinder pressure } \\
\text { measurement }\end{array}$ & AVL smart sampler \\
\hline SCR catalyst & $5.66 ” X 7.5 ”, 400 \mathrm{cpsi}$ \\
\hline
\end{tabular}

Table No 4: emmission norms 


\section{RESULTS AND DisCUSSIONS}

The output obtained from the experiment is plotted to determine the effect of the injection of urea solution at various concentration and to obtain the value of corresponding NOx as discussed above.

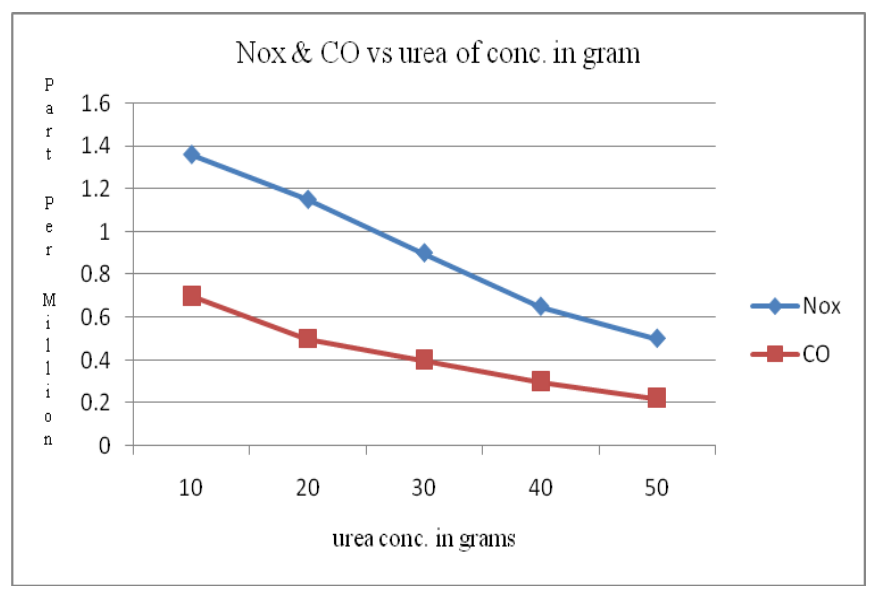

The percentage improvement in NOx and $\mathrm{CO}$ reduction is compared and it is observed that in new SCR system emission $\mathrm{s}$ are very closer to the Euro VI emission norms, which is highly beneficial for the proposed norms in India.
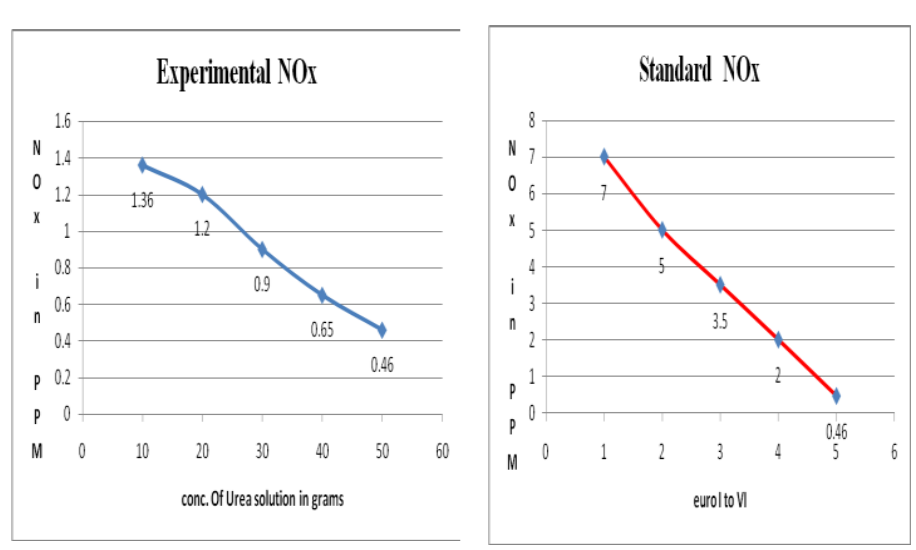

From the above comparison it is concluded that the distinct SCR system reduces the NOx emission.

\section{CONCLUSIONS}

From the research study it can be concluded that

- Urea acts as a good catalyst for the NOx reduction in diesel engine.

- Due to Urea injection in New SCR system in the tail pipe $\mathbf{6 7 . 5 \%}$ NOx reduction has been achieved.

- Simultaneously CO also gets decreases.
- New SCR the most harmful gases are minimized and Pollution can be controlled. The vehicle performance will be enhanced.

- By using this SCR system in CI engine emission are nearer the EURO VI emission norms.

\section{REFERENCES}

[1] M. Koebel, M. Elsener and M. Kleemann, "Urea-SCR: a promising technique to reduce NOx emissions from automotive diesel engines", Elsevier catalysis today, (2000), Pg. 335-345.

[2] Ioannis Gekas, Par Gabriel son and Keld Johansen, "UreaSCR catalyst system selection for fuel and PM optimized engines and a demonstration of a novel urea injection system", Society of Automotive Engineers, (2002-01-0289).

[3] Chun W. Lee and Ravi K. Srivastava, "Investigation of SCR impact on mercury speciation under simulated NOx emission control conditions ", Air \& Waste Management Association, (2004), Pg. 1560-1566.

[4] K. Chithambaramasari, N.V. Mahalakshmi and K. Jayachandran, "Application of SCR technique in NOx reduction of Diesel Engine Emission by Urea Injection Method", Canadian Journal on mechanical sciences \& Engineering, (December 2011), Vol.2 No.8.

[5] S. Gowthaman and K. Velmurugan, "Performance and Emission characteristics of direct injection diesel engine using Bio-diesel with SCR Technology", International Journal of Engineering Research and Applications, (October 2012), Vol.2 issue 5, Pg. 1083-1089.

[6] S. Ghosh, Dr. S.N. Chaudhuri and D. Dutta, "Reduction of NOx emission by urea injection and marine ferromanganese nodule as SCR of diesel engine", International Journal of Engineering Research \& Technology, (January 2013), Vol.2 issue 1 .

[7] Himangshu Sekhar Brahma and Dr.A. Veeresh Babu, "An experimental investigation on emission of neat Mahua biodiesel using urea-SCR", International Journal of Scientific \& Technology Research, (August 2013), Vol.2 issue 8.

[8] S. Ghosh, S.N. Chaudhuri and D. Dutta, "NOx reduction by using urea injection and marine ferromanganese nodule as SCR of a diesel engine fuelled with pongamia pinnata methyl ester ", International Journal of Modern Engineering Research, (April 2013), Vol.3 issue 2.

[9] R. Praveen \& S. natarajan, "Experimental study of selective catalytic reduction system on CI engine fuelled with diesel ethanol blend for NOx reduction with injection of urea solution" vol 6 No 2 Apr-May 2014 (ISSN: 0975-4024)

[10] Xinmei Yuan \& Hongqi Liu, Ying Gao "Diesel engine SCR control: Current development \& future challenges 2015(1:121-133)

[11] Kleemann, M., Dissertation Nr. 13401, ETH Zurich, 1999. 


\section{International Journal of Engineering Applied Sciences and Technology, 2019 \\ Vol. 4, Issue 6, ISSN No. 2455-2143, Pages 337-343 \\ Published Online October 2019 in IJEAST (http://www.ijeast.com)}

[12] H. Bosch, F. J. J. G. Janssen: "Catalytic Reduction of Nitrogen Oxides: A Review on the Fundamentals and Technology”, Catalysis Today, 2(369), 1988.

[13] Perry, R. A. And Siebers, D. L. Rapid reduction of nitrogen oxides in exhaust gas streams. Nature, 324, 1986,

[14] Hug, H. T., Mayer, A., and Hartenstein, A., SAE Technical Paper Series, 930363, Detroit, March 1-5, (1993).

[15] C.M.SCHAR, C.H. Onder and H.P. Geering, M Elsener, "Control of a Urea SCR catalytic Converter System for a Mobile Heavy Duty Diesel Engine", SAE Transactions 2003010776 (2003).

[16] Chakravarthy, K., Choi, J.-S., and Daw, S. Modeling SCR on zeolite catalysts - A summary of observations on SCR kinetics based on the open literature. In Eighth DOECLEERS Workshop, Dearborn, Michigan, 17-19 May 2005.

[17] Frickel, D.W., D'Addio, E., Lauterbacha, J.A., Lobo, R.F., "The Ammonia Selective Catalytic Reduction Activity of Copper Exchanged Small Pore-zeolites", App. Catal. B: Environmental, 102, 441-448, 2011.

[18] Koebel, M. and Strutz, E. O., "Thermal and Hydrolytic Decomposition of Urea for Automotive Selective Catalytic Reduction System: Thermo chemical and Practical Aspects," Ind. Eng. Chem. Res., 42, 2093-2100, 2003.

[19] Yim, S. D., Kim, S. J., Baik, J. H., Nam, I. S. et al., "Decomposition of U rea into NH3 for the SCR Process," Ind. Eng. Chem. Res., 43, 4856-4863, 2004.

[20] Girard, J., Snow, R., Cavataio, G., and Lambert, C., "The Influence of Ammonia to NOX Ratio on SCR Performance," SAE Technical Paper 2007-01-1581, 2007,

[22] Hünnekes, E., van der Heijden, P., and Patchett, J., "Ammonia Oxidation Catalysts for Mobile SCR Systems," SAE Technical Paper 2006-01-0640, 2006,

[23] Alano, E., Jean, E., Perrot, Y., Brunel, J. et al., "Compact SCR for Passenger Cars," SAE Technical Paper 2011-011318, 2011.

[24] Tan, J., Solbrig, C., and Schmieg, S., "The Development of Advanced 2-Way SCR/DPF Systems to Meet Future Heavy-Duty Diesel Emissions," SAE Technical Paper 201101-1140, 2011.

[25] Chatterjee, S., Conway, R., and Walker, A., "Emission Reduction in On-road Heavy Duty Diesel Applications with the Continuously Regenerating Technology (CRT®) Diesel Particulate Filter," SAE Technical Paper 2001-28-0049, 2001. [26] Walker, A., Allansson, R., Blakeman, P., Lavenius, M. et al., "The Development and Performance of the Compact SCRTrap System:A 4-Way Diesel Emission Control System," SAE Technical Paper 2003-01-0778, 2003,

[27] Sinya Sato et al, "The study of NOx reduction using Urea- SCR system for a heavy-duty diesel engine", 20045293 Proceedings of JSAE Annual Congress (2004).

[28] Satoshi Hiranuma et al, "Aftertreatment System for Commercial Diesel Engine (First Report), 20085359 Proceedings of JSAE Annual Congress (2008).
[29] Minoru Kowada et al "Development of PM and NOx Reduction Aftertreatment System for Heavy-Duty Commercial Vehicle,20105725 Proceedings of JSAE Annual Congress (2010).

[30] Hirose, S., Miyairi, Y., Katsube, F., Yuuki, K. et al., "Newly Developed Cordierite Honeycomb Substrate for SCR Coating Realizing System Compactness and Low Backpressure," SAE Technical Paper 2012-01-1079, 2012,

[31] Fujii S., Hirose S., Sakamoto H. et al., "Potential of Advanced Substrate Technology for SCR Emission Control System", CTI4th International Conference, NOx Reduction, Current and FutureSolution for On- and Off-Road Applications.

[32] Schaefer-Sindlinger A., Dinges T., Furuta Y. et al., "Latest Developments for Substrates and Filters in Heavy Duty Applications", SAE 2012 Heavy-Duty Diesel Emissions Control Symposium.

[33] Kikuchi S., Hatcho S., Okayama T., Inoue S. et al., "High Cell Density and Thin Wall Substrate for Higher Conversion Ratio Catalyst" 1999-01-0268.

[34] Paule, M., Mackensen, A., Binz, R., and Enderle, C., "Challenges for the Next Generation of BlueTEC Emission Technology," SAE Technical Paper 2011-01-0294, 2011,

[35] Hünnekes, E., van der Heijden, P., and Patchett, J., "Ammonia Oxidation Catalysts for Mobile SCR Systems," SAE Technical Paper 2006-01-0640, 2006

[36] Alano, E., Jean, E., Perrot, Y., Brunel, J. et al., "Compact SCR for Passenger Cars," SAE Technical Paper 2011-01$\underline{1318}$,

[37] Tan, J., Solbrig, C., and Schmieg, S., "The Development of Advanced 2-Way SCR/DPF Systems to Meet Future Heavy-Duty Diesel Emissions," SAE Technical Paper 2011$\underline{01-1140}, 2011$,

[38] Kleemann, M., Elsener, M., Koebel, M., and Wokaun, A., "Hydrolysis of Isocyanic Acid on SCR Catalysts," Ind. Eng. Chem. Res., 39, 4220-4126, 2000.

[39] Lundstrom, A., Snelling, T., Morsing, P., Gabrielsson, P. et al., "Urea Decomposition and HNCO hydrolysis over Titanium Dioxide, Fe-Beta and $\gamma$-Alumina", Applied Catalysis B: Environmental, 106, 273-279, 2011 